\title{
The relationship between internet addiction and eating attitudes and obesity related problems among university students
}

\author{
Üniversite öğrencilerinde internet bağımılı̆ğının yeme tutumları ve obezite \\ ilişkili sorunlara etkisi \\ Nermin Gündüz' ${ }^{1}$ Onur Gökçen², Fatma Eren³, Erkal Erzincan ${ }^{4}$, Özge Timur ${ }^{5}$, Hatice Turan ${ }^{6}$, Aslıhan Polat ${ }^{7}$ \\ ${ }_{1}^{1}$ Assis. Prof., Kütahya Saglik Bilimleri University Medical Faculty, Department of Psychiatry, Kütahya, Turkey -https://orcid.org/0000-0002-0188-6232 \\ 2M.D. Kütahya Sağlık Bilimleri University Medical Faculty, Evliya Çelebi Traning and Research Hospital, Department of Psychiatry, Kütahya, Turkey \\ https://orcid.org/0000-0001-9543-4239 \\ 3 M.D., Arakli State Hospital, Department of Psychiatry, Trabzon, Turkey https://orcid.org/0000-0002-3280-2687 \\ ${ }_{4}^{4}$ Assis. Prof., Erenköy Mental Health Traning and Research Hospital, Department of Psychiatry, İstanbul, Turkey https://orcid.org/0000-0001-6586-4430 \\ 5M.D., Erzurum Traning and Research Hospital, Department of Internal Medicine, Erzurum, Turkey https://orcid.org/0000-0002-7296-5536 \\ 6 M.D., İstanbul Special Moodist Psychiatry and Neurology Hospital, Department of Psychiatry, İstanbul, Turkey https://orcid.org/0000-0002-7130-6715 \\ ${ }^{7}$ Assoc. Prof., Kocaeli University Medical Faculty, Department of Psychiatry, Kocaeli https://orcid.org/0000-0001-9649-8701
}

\section{SUMMARY}

Objective: The aim of this research is to examine the prevalance of internet addiction and relationship between internet addiction (IA) and eating attitudes and quality of life in Erzurum Atatürk University faculty students. Method: A total of 466 faculty students from various faculties were included in the study. Sociodemographic data form created by researchers, Young Internet Addiction Scale (IAT), Obesity-Related Problems Scale (OR) and Eating Attitude Test-40 (EAT-40) were applied to the participants. Body Mass Index of the participants was calculated manually by the researchers. Results: 78.5 of the students were found to have IA. IA was found at a mild level in $52.6 \%$ of the students, moderate level in $24.2 \%$ and severe level in $1.7 \%$. There was a positive correlation between the total score of IAT and the alcohol use and psychiatric history. There was only a statistically significant relationship between the severity of IA and OR. There was no statistically significant relationship between Body Mass Index (BMI) and EAT-40. When the IAT and BMI, EAT-40 and OR correlation were examined, only a statistically significant but weak relationship was found in OR. Discussion: Although there are some cross-sectional studies, revealing the significant relationship between IA and abnormal eating attitudes, there are also studies revealing no significant relationship. But it is clear that there is no definitive result with the limitations of the current studies.

Key Words: Internet addiction, eating attitudes, obesity related problems, university students

\section{ÖZET}

Amaç: Bu çalışmanın amacı Erzurum Atatürk Üniversitesi öğrencileri arasında internet bağımlılığı yaygınlığı ve internet bağımlılığının öğrencilerin yeme tutumları ve yaşam kaliteleri üzerine etkisinin araştırılmasıdır. Yöntem: Çalışmaya farklı fakültelerden toplam 466 öğrenci dahil edilmiştir. Katılımcılara yazarlar tarafından hazırlanan sosyodemografik veri formu, Young İnternet Bağımlıı̆̆ı Testi, Şişmanlıkla illgili Sorunlar Ölçeği (ŞisÖ) ve Yeme Tutumu Testi-40 (YTT-40) uygulanmıştır. Vücut Kitle Indeksi (VKi) araştırmacılar tarafından hesaplanmıştır. Bulgular: Öğrencilerin \%78,5'inde internet bağımlılığı olduğu tespit edildi. Öğrencilerin $\% 52,6$ 'sında hafif şiddette, \%24,2'sinde orta/ılımlı düzeyde, \%1.7'sinde ise ağır düzeyde internet bağımlılığı olduğu tespit edilmiştir. İnternet bağımlılığı şiddeti ile alkol kullanımı arasında ve yine internet bağımlılığı şiddeti ile psikiyatrik hastalık özgeçmişi arasında istatistiksel olarak anlamlı ilişki olduğu bulunmuştur. Internet bağımlılığı şiddeti ile şisö arasında istatistiksel olarak anlamlı bir ilişki saptanmıştır. İnternet bağımlılığı şiddeti puanı ile VKi, YTT-40 puanı ve şisÖ arasında korelasyon bakıldığında yalnızca şisÖ'de istatistiksel olarak anlamlı olmakla beraber zayıf bir ilişki saptanmıştır. Sonuç: Her ne kadar bazı kesitsel çalışmalarda internet bağımlıı̆̆ı ile yeme tutumları arasında anlamlı bir ilişki olduğu ortaya konmuşken bazı çalışmalarda ise bu ilişki ortaya konamamıştır. Bu alanda yapılan güncel çalışmaların kısıtııı̆ı nedeni ile aradaki ilişki net değildir.

Anahtar Sözcükler: İnternet bağımlılığı, yeme tutumları, obezite ilişkili sorunlar, üniversite öğrencileri 


\section{INTRODUCTION}

Problematic internet use or internet addiction (IA) can be defined as inability to prevent the excessive use of internet, loss of importance of time spent without being connected to internet, appearance of excessive tension and aggression in the absence of being connected to internet and the gradual deterioration of professional, school, social and family life (1).

Although IA can be seen almost any age, young internet users, especially those between 18 and 24 years, have reported to have greater risk for IA (2). The prevalence of IA among adolescents has been found to be $4.4 \%$ in a wide range of studies in European countries (3). It is stated that this rate is increased with the increase of internet accessibility in the studies carried out afterwards (4). In studies conducted in Turkey, IA among university students have been reported to be between $7.2 \%$ and $12.2 \%$ $(5,6)$.

Spending more time on internet can negatively affect young people's daily life. In some cross-sectional studies, it has been stated that IA have negative effects on many lifestyle-related factors such as irregular eating habits, management and deterioration of time, physical dysfunction and shortening of the sleep period in adolescents (7-10).

IA not only disturbs the individuals' physical health but also disturbs the mental health (11-17). There are studies about relationship between IA and depressive symptoms (11), obsessive compulsive symptoms (12), social phobia (13), attention deficit hyperactivity disorder (14), anxiety symptoms (15), eating disorders (16), alcohol addiction (17). But, studies about the relationship between IA and abnormal eating attitudes is relatively rare. Also there is no study investigating the relationship between obesity related problems and IA or problematic internet use. Although there are some cross-sectional studies, revealing the significant relationship between IA and abnormal eating attitudes $(7,18,40)$, and there are also studies revealing no significant relationship $(19,20)$. For example, in a study conducted among 2036 Chinese students, authors reported no significant correlation between Young IAT and EAT subscales (20). On the other hand in another study conducted by Alpaslan and colleagues (2015) among 584 students, authors revealed positive correlation between EAT and Young IAT (18). But it is clear that there is no definitive result with the limitations of the current studies (21). Results of the studies investigating the relationship between eating attitudes and IA depend on material, statistical methodology, mean age of the sample group and sample size.

Considering the increasing use of internet among university students, this group is thought to be particularly sensitive to IA because of time they spend on internet. Also university students are a risky group both in terms eating disorders. In this study, we aimed to examine the prevalence of IA and also relationship between IA and eating attitudes and obesity related problems among Erzurum Atatürk University students.

\section{METHODS}

This study was carried out among the students from different faculties at Erzurum Atatürk University. Ethical committee approval was obtained from Erzurum Regional Training and Research Hospital for the study. With the approval of the ethics committee, the necessary permissions were obtained by applying to the deans of Erzurum Atatürk University Faculties. In this cross-sectional study, necessary information concerning the questionnaires and the aim of the study was given to the students prior to the interview. Sociodemographic data form created by researchers, Young Internet Addiction Scale, Obesity-Related Problems Scale and Eating Attitude Test 40 were applied to the participants. The study was conducted in accordance with the principles of the Declaration of Helsinki.

\section{Participants}

A total of 466 students from various faculties were included in the study. Of the 466 students 106 were from engineering faculties, 98 were from physical education sports high school, 32 were from education faculty, 102 were from social sciences, 8 were 
from health sciences and 120 were from other faculties.

\section{Instruments}

Sociodemographic Data Form: In this form, the participants were asked about personal information such as age, gender, duration of daily internet use, living place, smoking, alcohol use, substance use, psychiatric history and weight and height. Body mass index (BMI) was calculated manually by using the formula weight $(\mathrm{kg}) /$ height2 $(\mathrm{m} 2)$.

Young Internet Addiction Scale (IAT): The Young's Internet Addiction questionnaire consists of 20 items ranked on a 6 options likert scale from never $=0$ to always $=5$, with the minimum and maximum score from zero to 100 , respectively (22). The validity and reliability study in Turkey was carried out by Bayraktar et al (23). Higher the score, the greater is the level of addiction and creation of problems resulting from such internet use. The severity impairment index is determined as follows: None: 0-30 points, Mild: $31-49$ points, Moderate: 50-79 points, Severe: $80-100$ points.

Eating Attitudes Test 40 (EAT-40): This questionnaire was developed by Garner and Garfinkel as a self-report scale to measure anorexia nervosa symptoms (24). It has validity and reliability in Turkish adapted by Savaşır and Erol (25).

\section{Analysis of the data}

Data analysis was done using SPSS version 17 (Statistical Package for Social Science). The variables were investigated using visual (histograms, probability plots) and analytical methods (Kolmogorov Smirnov test) to determine whether or not they are normally distributed. Comparisons of non-parametric variables between groups were performed by using Mann-Whitney $U$ test. The Chi-square test or Fisher's exact test, where appropriate, was used to compare proportions in different groups. Correlations were determined by using the Spearman test. $\mathrm{P}<0,05$ was considered to indicate a significant difference.
Obesity-Related Problems Scale (OR): This scale was developed from the Health-Related Quality of Life Questionnaire (HRQoL) to consider the impact of the psychosocial functionality section of quality of life in obese individuals. It contains eight likert-type items. Higher the scores show that psychosocial functionality is negatively affected in the individual. The highest total scale score is 32 , and the lowest score is 8 (26). Turkish validity and reliability of this scale was conducted by Polat et al (27).

\section{RESULTS}

Of the 466 students $49.4 \%(n=230)$ were female and $50.6 \%(n=236)$ were male. The mean age of the participants included in the study was $21.95( \pm$ 2.56) years. $36.5 \%(n=170)$ were living with their families, $29.6 \%(n=138)$ were staying at student house and $33.9 \%(n=158)$ were staying at student hostel. The majority of the group $(52.8 \%$; $n=245)$ was using internet over 4 hours. Sociodemographic data of the participants was presented in Table 1.

The mean value of the BMI of the participants included in the study was $21.60( \pm 3.15) \mathrm{kg} / \mathrm{m} 2$. $78.5 \%(\mathrm{n}=366)$ of the students were found to have IA. IA was found at a mild level in $52.6 \%(\mathrm{n}=245)$ of the students, moderate level in $24.2 \%(n=113)$ and severe level in $1.7 \%(\mathrm{n}=8)$. The distribution of mean, median, and standard deviation data of IAT according to sociodemographic data was presented in Table 2.

There was a statistically significant relationship between the values of mean, median and std deviation of IAT and alcohol use $(\mathrm{p}=0.016)$ and duration of daily internet use $(\mathrm{P}<0.05)$ (Table 2$)$. IAT was found to be highest among social sciences with the score of $45.87 \pm 19.95$. IAT was found to be lowest among education faculty with the score of $29.81 \pm 19.45(p=0.000)$. The distribution of severity of IA according to sociodemographic data was presented in Table 2 .

There was a significant relationship between BMI according to faculties of the participants $(\mathrm{p}=0.001)$. BMI was minimum among social sciences with $20.67 \pm 3.22 \mathrm{~kg} / \mathrm{m} 2$ (Table 3 ). 
Gunduz N, Gokcen O, Eren F, Erzincan E, Timur O, Turan H, Polat A.

Table 1: Sociodemographic Data

\begin{tabular}{|c|c|c|c|c|c|c|c|c|}
\hline & & Engineering & PESHS & Education & $\begin{array}{l}\text { Social } \\
\text { Sciences }\end{array}$ & Others & $\begin{array}{l}\text { Health } \\
\text { Sciences }\end{array}$ & Total \\
\hline \multirow[t]{2}{*}{ Gender } & Female & 49 & 29 & 19 & 63 & 64 & 6 & 230 \\
\hline & Male & 57 & 69 & 13 & 39 & 56 & 2 & 236 \\
\hline \multirow{4}{*}{$\begin{array}{l}\text { Students } \\
\text { Living } \\
\text { Place }\end{array}$} & With & $25(23.6)$ & $40(40.8)$ & $9(28.1)$ & $35(34.3)$ & $59(49.2)$ & $2(25)$ & 170 \\
\hline & Family & & & & & & & \\
\hline & $\begin{array}{l}\text { Student } \\
\text { House }\end{array}$ & $42(39.6)$ & $36(36.7)$ & $8(25)$ & $24(23.5)$ & $25(20.8)$ & $3(37.5)$ & 138 \\
\hline & $\begin{array}{l}\text { Student } \\
\text { Hostel }\end{array}$ & $39(36.8)$ & $22(22.4)$ & $15(46.9)$ & $43(42.2)$ & $36(30)$ & $3(37.5)$ & 158 \\
\hline \multirow{5}{*}{$\begin{array}{l}\text { Daily } \\
\text { Internet } \\
\text { Usage } \\
\text { Time }\end{array}$} & $<30 \mathrm{~min}$ & $4(3.8)$ & $4(4.1)$ & $4(12.5)$ & $5(4.9)$ & $8(6.7)$ & $0(0)$ & 20 \\
\hline & $30 \mathrm{~min}-2 \mathrm{~h}$ & $23(21.7)$ & $33(33.7)$ & $10(31.3)$ & $12(11.8)$ & $15(12.5)$ & $3(37.5)$ & 96 \\
\hline & $2-3 \mathrm{~h}$ & $23(21.7)$ & $16(16.3)$ & $9(28.1)$ & $11(10.8)$ & $13(10.8)$ & $1(12.5)$ & 73 \\
\hline & $3-4 h$ & $5(4.7)$ & $11(11.2)$ & $3(9.4)$ & $4(3.9)$ & $2(1.7)$ & $2(25)$ & 27 \\
\hline & $\geq 4 \mathrm{~h}$ & $51(48.1)$ & $34(34.7)$ & $6(18.8)$ & $70(68.6)$ & $82(68.3)$ & $2(25)$ & 245 \\
\hline \multirow[t]{2}{*}{ Smoking } & yes & $57(53.8)$ & $44(44.9)$ & $16(50)$ & $44(43.1)$ & $65(54.2)$ & $3(37.5)$ & 229 \\
\hline & no & $49(46.2)$ & $54(55.1)$ & $16(50)$ & $58(56.9)$ & $55(45.8)$ & $5(62.5)$ & 237 \\
\hline \multirow[t]{2}{*}{ Alcohol } & yes & $42(39.6)$ & $17(17.3)$ & $6(18.8)$ & $15(14.7)$ & $37(30.8)$ & $2(25)$ & 119 \\
\hline & no & $64(60.4)$ & $81(82.7)$ & $26(81.2)$ & $87(85.3)$ & $83(69.2)$ & $6(75)$ & 347 \\
\hline \multirow[t]{2}{*}{ Substance } & yes & $15(14.2)$ & $2(2)$ & $2(6.3)$ & $2(2)$ & $7(5.8)$ & $0(0)$ & 28 \\
\hline & no & $91(85.8)$ & $96(98)$ & 30 (93.7) & 100 (98) & 113(94.2) & $8(100)$ & 438 \\
\hline
\end{tabular}

PESHS: Physical Education Sports High School

There was a significant relationship between IAT total score according to faculties of the participants $(p=0.000)$. IAT was found to be highest among social sciences with the score of $45.87 \pm 19.95$ (Table 3).

There was a significant relationship between EAT 40 total score according to faculties of the participants $(p=0.029)$. EAT 40 was found to be highest among social sciences with the score of $16.10 \pm 11.85$. EAT 40 was found to be minimum among health sciences with the score of $22.33 \pm 15.13$ (Table 3).

There was a significant relationship between OR total score according to faculties of the participants $(\mathrm{p}=0.000)$. OR was found to be highest among social sciences with the score of $17.71 \pm 7.30$ (Table
3). Mean, median, and std deviation of BMI and scales according to faculties of the participants was presented was in Table 3.

Correlations between severity of IA and BMI, EAT-40, OR is presented in Table 4. When the IAT and BMI, EAT-40 and OR correlation were examined, only a statistically significant but weak relationship was found in OR (Table 4).

\section{DISCUSSION}

In this study, we examined the prevalance of IA; relationship between IA and eating attitudes and obesity related problems among the students from different faculties from Erzurum Atatürk University. 
The relationship between internet addiction and eating attitudes and obesity related problems among university students

Table 2: The distribution of mean, median, and standart deviation of IAT according to sociodemographic data

\begin{tabular}{|c|c|c|c|c|c|}
\hline & & Mean & Median & SD & $\mathrm{p}$ \\
\hline \multirow[t]{2}{*}{ Gender } & Female & 38.35 & 36.00 & 19.52 & \multirow[b]{2}{*}{0.484} \\
\hline & Male & 36.90 & 36.00 & 19.64 & \\
\hline \multirow[t]{2}{*}{ Smoking } & Yes & 37.75 & 36.00 & 18.25 & \multirow[t]{2}{*}{0.800} \\
\hline & No & 37.49 & 35.00 & 20.81 & \\
\hline \multirow[t]{2}{*}{ Alcohol } & Yes & 40.97 & 38.00 & 17.3 & \multirow[t]{2}{*}{0.016} \\
\hline & No & 36.47 & 34.00 & 20.19 & \\
\hline \multirow[t]{2}{*}{ Substance } & Yes & 40.61 & 38.00 & 16.11 & \multirow[t]{2}{*}{0.274} \\
\hline & No & 37.43 & 36.00 & 19.77 & \\
\hline \multirow{5}{*}{$\begin{array}{l}\text { Duration of Daily } \\
\text { internet use }\end{array}$} & $<30 \mathrm{~min}$ & 19.88 & 16.00 & 16.63 & \multirow{5}{*}{$<0.05$} \\
\hline & $30 \mathrm{~min}-2 \mathrm{~h}$ & 25.64 & 25.00 & 14.73 & \\
\hline & 2-3 hours & 29.07 & 29.00 & 15.48 & \\
\hline & 3-4 hours & 32.89 & 32.00 & 17.55 & \\
\hline & $\geq 4$ hours & 47.07 & 46.00 & 17.74 & \\
\hline \multirow{3}{*}{$\begin{array}{l}\text { Student s Living } \\
\text { Place }\end{array}$} & With Family & 39.33 & 39.00 & 20.94 & \multirow{3}{*}{0.176} \\
\hline & Student House & 35.16 & 33.50 & 17.00 & \\
\hline & Student Hostel & 37.92 & 36.50 & 20.05 & \\
\hline \multirow{2}{*}{$\begin{array}{l}\text { Psychiatric } \\
\text { history }\end{array}$} & Yes & 35.62 & 34.50 & 20.98 & \multirow[t]{2}{*}{0.18} \\
\hline & No & 38.22 & 36.50 & 19.12 & \\
\hline \multirow[t]{6}{*}{ Faculty } & Engineering & 32.08 & 34.00 & 13.83 & \multirow{6}{*}{0.000} \\
\hline & PESHS & 30.32 & 28.00 & 19.42 & \\
\hline & Education & 29.81 & 29.00 & 19.45 & \\
\hline & Social Sciences & 45.87 & 45.50 & 19.95 & \\
\hline & Health Sciences & 34.33 & 27.50 & 22.45 & \\
\hline & Others & 43.75 & 43.50 & 19.31 & \\
\hline
\end{tabular}

PESHS: Physical Education Sports High School

$78.5 \%$ of the students were found to have IA. IA was found at mild level in $52.6 \%$ of the students, moderate level in $24.2 \%$ and severe level in $1.7 \%$; in accordance with literature $(8,28)$. Similarly, in a study conducted by Chaudhari et al., in an attempt to determine the prevalence of IA in university students in Western Maharashtra, India, prevalence of IA was reported to be $58.87 \%$, and it was reported that $51.42 \%$ had mild and $7.45 \%$ had moderate IA (28). However, in some studies the prevalance of IA was found to be lower $(29,30)$. There is also a study in which the prevalence of IA was found to be higher (31). This difference in prevalence may be related to some factors like the heterogeneity of the sample groups, sample size, sociocultural differences, access to internet, different diagnostic tools used in the studies (28).

There are studies like ours, showing nosignificant relationship between IA and gender as well as studies showing that IA is more frequent among males $(28,29,32)$. Chou et al. suggested that males are at risk for IA due to their stereotyped use of sexual content whereas females may be asymptomatic or have limited symptoms for IA (33). Morahan-
Martin and Schumacker have described this difference between genders because of the online activities such as gaming, pornography and gambling that are more frequently used by males (34).

Although Asiri found that IA scale total scores of the students living alone were higher than the other groups and the scores of the residents were found to be lower than the other groups (35), we found no significant relationship between IA scale total score and living place consistent with the results of the study conducted by Ghamari et al. (29). Researchers have explained that this may be due to the fact that residents have fewer opportunities to connect to internet.

There is a significant relationship between IA scale total score and the participants' daily internet use periods. As the duration of internet use increased, the total score of the scale increased. This is in accordance with the other studies $(28,32)$.

Although we determined significant relation between IA scale and alcohol use, we did not deter- 
Gunduz N, Gokcen O, Eren F, Erzincan E, Timur O, Turan H, Polat A.

Table 3: Mean, median, and standart deviation of BMI and scales according to faculties of the participants

\begin{tabular}{|c|c|c|c|c|c|c|c|c|}
\hline & & Engineering & PESHS & Education & $\begin{array}{l}\text { Social } \\
\text { Sciences }\end{array}$ & Others & $\begin{array}{l}\text { Health } \\
\text { Sciences }\end{array}$ & $\mathrm{p}$ \\
\hline \multirow[t]{3}{*}{ BMI } & Mean & 22.53 & 21.87 & 21.95 & 20.67 & 21.21 & 22.45 & 0.001 \\
\hline & Median & 22.50 & 21.65 & 21.70 & 20.10 & 21.00 & 22.45 & \\
\hline & SD & 3.42 & 2.91 & 3.26 & 3.22 & 2.79 & 2.78 & \\
\hline \multirow{3}{*}{$\begin{array}{l}\text { IA total } \\
\text { score }\end{array}$} & Mean & 32.08 & 30.32 & 29.81 & 45.87 & 43.50 & 34.33 & 0.000 \\
\hline & Median & 34.00 & 28.00 & 29.00 & 45.50 & 19.31 & 27.50 & \\
\hline & SD. & 13.83 & 19.42 & 19.45 & 19.95 & 16.82 & 22.45 & \\
\hline \multirow[t]{3}{*}{ EAT 40} & Mean & 17.75 & 19.81 & 16.44 & 16.10 & 16.82 & 22.33 & 0.029 \\
\hline & Median & 15.00 & 16.00 & 14.00 & 12.00 & 12.00 & 17.00 & \\
\hline & SD & 10.18 & 12.79 & 8.25 & 11.85 & 12.19 & 15.13 & \\
\hline \multirow[t]{3}{*}{ OR } & Mean & 14.87 & 12.20 & 13.44 & 17.71 & 16.81 & 15.67 & 0.000 \\
\hline & Median & 13.50 & 9.00 & 11.50 & 18.00 & 16.00 & 17.00 & \\
\hline & SD & 7.55 & 6.24 & 6.80 & 7.30 & 8.14 & 6.50 & \\
\hline
\end{tabular}

PESHS: Physical Education Sports High School, IA: Internet Addiction; BMI: Body Mass Index;

EAT 40: Eating Attitudes Test 40; OR: Obesity-Related Problems Scale SD: Standart Deviation

mine such relationship between IA scale and substance use and smoking. Unlike our study, in a study conducted by Morioka et al., IA and excessive internet use were higher among smokers (36). It has been reported that problematic internet use may be associated with other risky behaviors and may be an important early predictor of substance use especially during adolescence $(37,38)$.

Our study showed that IA varied according to faculties of the students. Our result about IA among social sciences students is an accordance with Özcan et al's study (39). Özcan and collegaues found a higher level of problematic internet use among social sciences students (39). In a study designed like our study and conducted by Çelik and collegaues found that communication and education faculty students had higher levels of problematic internet use than medical faculty students (7). Comparing with the other faculties, social sciences generally have less compact academic programs. Due to having less compact academic programs, students of social sciences usually have excessive free time out of school. This may result in excessive communicating, shopping, gambling, online gaming, information collection.
We found no significant relationship between IA and eating attitudes. However, a statistically significant relationship was found between IA and obesity related problems at weak level. When participants with BMI over 25 were assessed separately, there was no significant relationship between IA and obesity related problems. There are studies suggesting no significant relationship between IA and eating attitudes consistent with our finding (19, 20). For example, in a study conducted among 2036 Chinese students, participants were assessed with online Young IAT, EAT, Beck Depression Inventory and DSM-IV criteria for bulimia (20). Of the whole group, 61 students who had severe IA according to the Young IAT were compared with 70

Table 4: Correlations between the scales

\begin{tabular}{llll}
\hline & IAT & EAT & OR \\
\hline BMI & -0.077 & $-0.103^{*}$ & $0.178^{* *}$ \\
\hline IAT & 1 & -0.51 & $0.297^{* *}$ \\
\hline EAT & -0.051 & 1 & -0.89 \\
\hline OR & $0.297^{* *}$ & -0.89 & 1
\end{tabular}

IAT: Internet Addiction Test; BMI: Body Mass Index; , EAT 40: Eating Attitudes Test; OR: Obesity-Related Problems Scale $\mathrm{p}<0.05 * * \mathrm{p}<0.01$ 
students who did not have IA according to the same test. As a result, female students having severe IA were rated higher scores in the subscales of EAT compared to those who did not have IA. Male students also received higher scores on some subscales too. In terms of bulimia criteria, there was a significant difference between addicted and non-addicted group. It was also reported that this relation was mediated by depression. On the other hand, authors reported no correlation between Young IAT and EAT subscales (20). In another study conducted by Canan et al. among 1938 students aged between 14 and 18, 12\% of the participants had IA (3.5\% severe level) (19). Authors reported no correlation between Young IAT scores and EAT subscales. However, BMI, IAT, and time spendig online were found to be correlated. Authors also suggested that the use of the internet mainly for academic purposes was associated with a decline in BMI (19).

Although we found no significant relationship between IA and eating attitudes among all of the participants, we determined significant findings about IA, EAT 40, OR and BMI according to faculties of the participants. EAT 40 and OR was found to be highest among social sciences as we found the highest scores of IA among this student group. The increase in the total score obtained from EAT 40 is considered to be an indicator of the deterioration in eating attitudes. So, finding the highest scores for EAT 40 and IA among social sciences was not suprising. The increase in the total score obtained from OR shows that psychosocial functionality is negatively affected in individuals. Also BMI was found to be lowest among social sciences. There are also studies showing significant relation between IA and disordered eating attitudes (7). In a study conducted by Çelik et al (2015), 315 university students were evaluated with EAT and The Problematic Internet Use Scale (7). Authors reported positive correlation between EAT and The Problematic Internet Use Scale (7). In another study conducted by Alpaslan and his colleagues (2015) among 584 students, IA was determined in $10.1 \%$ of the participants according to Young IAT. Authors revealed positive correlation between EAT and Young IAT (18). Also according to EAT, disordered eating attitude was found in $15.2 \%$ of the participants and the pre- sence of disordered eating attitudes, male gender, and higher BMI scores were revelaed to be the strongest predictors for IA (18). Also in another study conducted by Tao et al. (2009) among 1199 participants of Chinese secondary school and college students aged between 12 and 25, Young IAT had been used and the internet use patterns of the participants had been questioned (40). EAT-26 and The Eating Disorder Inventory (EDI) had also been applied to these participants. As a result of this study, $54(4.5 \%)$ of the participants were evaluated as internet addicts. This prevalance is significantly lower than our prevalance. This may be due to the inclusion of secondary school students in this study, which is different from our study. Also in female problematic internet users diet behaviors, oral control and bulimia subscales had been found to be higher compared with non-addicts. In male internet addicts, oral control subscale had been found to be higher when male participants with BMI over 25 were excluded (40). In another study conducted among 392 participants aged between 19 and 35, were assessed with online Young IAT, EAT, and Body Image Avoidance Questionnaire (41). In this study, participants were asked about time spent online and on which web sites. $40(10.2 \%)$ of the participants were evaluated as internet addicts. IA symptoms like spending time on social media sites like Facebook, MSN and body image avoidance were found to be significant predictors of disordered eating among only female participants. This relationship was not found on spending time online on other websites and not found among male participants. Also, all time spent online was associated with disordered eating attitudes in female participants. But, there was no significant relationship between all time spent online and body image avoidance. These relationships were not found among male participants. Authors suggested that individuals with having anxiety related to body image and individuals with disordered eating attitudes may be using social media as a way of coping rather than enter into an environment that would increase their psychopathology (41). In a nationwide study conducted among Korean adults, participants had been assessed with Korean Internet Addiction Proneness Scale for Youth-Short Form, BMI as dividing the participants into three groups: underweight, normal weight and over weight and at least weight control behavior. As a result of the 
study it had been reported that adults having inappropriate weight control behavior had been found more likely to have problematic internet use. On the other hand, underweight, overweight, and obese adults had been reported to more likely to have problematic internet use (42).

There are studies suggesting significant relation between IA and obesity $(43,44)$. In a study conducted by Eliacik et al. (45) among obese adolescents and control groups, participants had been assessed with IA scale devoled by Günüç and Kayri (46), the Pediatric Quality of Life Inventory, the Pittsburgh Sleep Quality Index, and the Epworth Sleepiness Scale. As a result of this study, it has been suggested that obese adolescents had been more likely to have IA and lower quality of life compared to controls (45).

While there was no relationship between BMI and IA in our study, we determined a weak significant relation between IAT and OR. There are some possible reasons to explain the different results. First of all, the concept of IA which is not included in the DSM diagnostic series is not clear yet. There is also debate argues that the quality of online activity is important as well as the amount of time spent online (19). This can explain the different conclusions found in the relevant studies. Canan and colleagues (19) found that the use of the internet mainly for academic purposes was associated with a decline in BMI, and Rodgers et al. (45) found an association between avoidance and disordered eating attittudes in female participants and social media sites such as Facebook and MSN.

There are also debates that IA is a set of pathologies that vary according to online activities, as well as debates that internet is an instrument for addiction, and that behavioral addiction is through the activity on internet (like online gambling) $(47,48)$. Another reason for different results found in the studies is related about the scales used. Although the Young IAT is still the most frequently used scale in the IA studies, internet has changed much in our lives since the test was first set up, and there are criticisms about the update of this scale (49). Moreover, the results of having a personal computer may not have been updated with the spread of smartphones. We think that this is the most impor- tant reason for the high IA scores in our study. In this context, we are sure that there is a need for upto-date structured or semi-structured scales that explore the concept of IA.

Another important point of view that affects the results is related about eating attitudes. Disordered eating attitudes can be found in various pathologies such as obesity, binge eating disorder, and anorexia nervosa. Also the differences between the results of the studies may have been caused by the use of different scales and by not investigating a specific diagnosis of eating disorder.

There are some limitations of the study. First, only the self-report scale was used to determine IA in the participants. We didn't interview with the participants. Also, since there are a group of students who refuse to participate, this can reduce the power of the study. Because of the cross-sectional design of the study, it may be difficult to establish causal relationship.

In conclusion, the main finding of the present study is that IA and obesity related problems are positively correlated among university students in our country. Adolescents are particularly vulnerable to developing addictive behavioral patterns like problematic internet use and health-compromising behaviors, such as irregular dietary habits, alcohol use, and smoking habits. Adolescents can use the internet as a way of coping with their adaptation problems in early transition years, and this progression may become more permanent in the future and become a risk to the development of IA. A prospective approach should be used to confirm these results as well as establish strategies for better detection and management of IA and disordered eating attitudes when working with adolescents. Also it is clear that there is a need for followup studies using structured or semi-structured scales that allow the detection of specific diagnostic groups.

Correspondence address: Assis. Prof. Nermin Gunduz, Saglik Bilimleri University, Medical Faculty, Department of Psychiatry, Kutahya, Turkey ngunduz2798@hotmail.com 


\section{REFERENCES}

1. Arısoy, Ö. İnternet bağımlılığı ve tedavisi. Psikiyatride Güncel Yaklaşımlar 2009;1:55-67.

2. Thatcher A, Goolam S. Defining the South African Internet "Addict": prevalence and biographical profiling of problematic Internet users in South Africa. South AfricanJournal of Psychology 2005;35:766-792.

3. Durkee T, Kaess M, Carli V, Parzer P, Wasserman C, Floderus B. Prevalence of pathological Internet use among adolescents in Europe: Demographic and social fac $\neg$ tors. Addiction 2012;107:2210-2222.

4. Kaess M, Parzer P, Brunner R, Koenig J, Durkee T, Carli V, Wassermann C. Pathological Internet Use Is on the Rise Among European Adolescents. Journal of Adolescent Health 2016;59:, 236-239.

5. Dalbudak E, Evren C, Aldemir S, Coskun KS, Ugurlu H, Yildirim FG. Relationship of Internet Addiction Severity with Depression, Anxiety, and Alexithymia, Temperament and Character in University Students. Cyberpsychology, Behavior, and Social Networking 2013a;16:272-278.

6. Dalbudak E, Evren C, Topcu M, Aldemir S, Coskun KS, Bozkurt M, Evren B, Canbal M. Relationship of internet addiction with impulsivity and severity of psychopathology among Turkish university students. Psychiatry Research 2013b;210: 1086-1091.

7. Celik ÇB, Hatice Odacı H, Bayraktar N. Is problematic internet use an indicator of eating disorders among Turkish university students? Eat Weight Disord 2015;20:167-172.

8. Gündüz N, Timur Ö, Erzincan E, Turan H, Gökçen O, Eren F, Polat A. Internet Addiction and Excessive Daytime Sleepiness and Quality of Life Among Medical Faculty Students. Current Addiction Research 2017;1:56-64.

9. Kim J, Hong H, Lee J, Hyun, MH. Effects of time perspective and self-control on procrastination and Internet addiction. Journal of Behavioral Addictions 2017;6(2), 229-236.

10. Lam LT, Peng ZW, Mai JC, Jing J. Factors associated with Internet addiction among adolescents. Cyber psychol Behav 2009;12:551-555.

11. Scimeca G, Bruno A, Cava L, Pandolfo G, Muscatello MR, Zoccali R.The relationship between alexithymia, anxiety, depression, and internet addiction severity in a sample of Italian high school students. ScientificWorld Journal 2014:504376.

12. Kim M, Lee TH, Choi JS, Kwak YB, Hwang WJ, Kim T, Lee JY, Lim JA, Park M, Kim YJ, Kim SN, Kim DJ, Kwon JS. Neurophysiological correlates of altered response inhibition in internet gaming disorder and obsessive-compulsive disorder: Perspectives from impulsivity and compulsivity. Sci Rep 2017;7:41742.

13. Yayan EH, Arikan D, Saban F, Gürarslan Baş N, Özel Özcan Ö. Examination of the Correlation Between Internet Addiction and Social Phobia in Adolescents. West $J$ Nurs Res 2016;39:1240-1254.

14. Tateno M, Teo AR, Shirasaka T, Tayama M, Watabe M, Kato TA. Internet addiction and self-evaluated attention-deficit hyperactivity disorder traits among Japanese college students.
Psychiarty Clin Neurosci 2016;70:567-572.

15. Scimeca G, Bruno A, Cava L, Pandolfo G, Muscatello MR, Zoccali $\mathrm{R}$. The relationship between alexithymia, anxiety, depression, and internet addiction severity in a sample of Italian high school students. ScientificWorld Journal 2014:504376.

16. Tao Z, Wu G, Wang Z. The relationship between high residential density in student dormitories and anxiety, binge eating and Internet addiction: a study of Chinese college students. Springerplus. 2016;15;5:1579.

17. Bibbey A, Philips AC, Ginty AT, Carroll D. Problematic Internet use, excessive alcohol consumption, their comorbidity and cardiovascular and cortisol reactions to acute psychological stress in a student population. J Behav Addict 2015;4:44-52.

18. Alpaslan AH, Kocak U, Avci K, Uzel Tas H. The association between internet addiction and disordered eating attitudes among Turkish high school students. Eat Weight Disord 2015;20:441-448.

19. Canan F, Yildirim O, Ustunel TY, Sinani G, Kaleli AH, Gunes C, Ataoglu A. The relationship between internet addiction and body mass index in Turkish adolescents. Cyberpsychol Behav Soc Netw 2014;17:40-45.

20. Tao Z. The relationship between internet addiction and bulimia in a sample of Chinese college students: depression as partial mediator between internet addiction and bulimia. Eat Weight Disord 2013;18:233-243.

21. Canan F. The relationship between internet addiction and eating disorders. Eat Weight Disord 2016;21:137-138.

22. Young KS. Internet addiction: The emergence of a new clinical disorder. Cyber Psychology \& Behavior 1998;1(3): 237-244.

23. Bayraktar, F. Internet Kullanımının Ergen Gelisimindeki Rolü. Yayınlanmamış Yüksek Lisans Tezi. İzmir: EÜ. Sosyal Bilimler Enstitüsü. 2001.

24. Garner, DM, Garfinkel PE. The Eating Attitudes Test: An index of the symptoms of anorexia nervosa. Psychological medicine 1979;9:273-279.

25. Savaşır I, Erol N. Yeme tutumu testi: Anoreksiya nevroza belirtileri indeksi. Psikoloji Dergisi, 1989;7:19-25.

26. Karlsson J, Taft C, Sjöström L, Torgerson JS, Sullivan M. Psychosocial functioning in the obese before and after weight reduction: construct validity and responsiveness of the Obesityrelated Problems scale. Int $\mathbf{J}$ Obes Relat Metab Disord 2003;27:617-30.

27. Polat A, Turan H, Erzincan E, Tural U. Şişman Bireylerde Şişmalık İle İlgili Sorunlar Ölçeği Türkçe Geçerlik ve Güvenirlik Çalışması, 50. Ulusal Psikiyatri Kongresi, 2014, Poster Bildiri No:211

28. Chaudhari B, Menon P, Saldanha D, Abhinav Tewari A, Bhattacharya L. Internet addiction and its determinants among medical students. Ind Psychiatry J 2015;24:158-162.

29. Ghamari F, Mohammadbeigi A, Mohammadsalehi N, Hashiani AA. Internet Addiction and Modeling its Risk Factors in Medical Students. Iran Indian J Psychol Med 2011;33:158162. 
30. Tsimtsiou Z, Haidich AB, Spachos D, Kokkali S, Bamidis P, Dardavesis T, Arvanitidou M. Internet addiction in Greek medical students: an online survey. Acad Psychiatry 2015;39:300-4. 3

31. Pramanik T, Sherpa MT, Shrestha R. Internet addiction in a group of medical students: a cross sectional study. Nepal MedColl J 2012;14:46-8.

32. Salehi M; Khalili MN; Hojjat SK; Salehi M; Danesh A Prevalence of Internet Addiction and Associated Factors Among Medical Students From Mashhad, Iran in 2013. Iran Red Crescent Med J 2014;16:e17256

33. Chou C, Condron L, Belland JC. A review of the research on Internet addiction. Educ Psychol Rev 2005;17:363-388.

34. Morahan-Martin JM, Schumacker P. Incidence and correlates of pathological internet use. Comput Human Behav 2000;16:13-29.

35. Asiri S, Fatemeh Fallahi F, Ghanbari A, Kazemnejad-leili E Internet Addiction and its Predictors in Guilan Medical Sciences Students, 2012. Nurs Midwifery Stud. 2013;2:234-239.

36. Morioka H, Itani O, Osaki Y, Higuchi S, Jike M, Kaneita Y, Kanda H, Nakagome S, Ohida T,Association Between Smoking and Problematic Internet Use Among Japanese Adolescents: Large-Scale Nationwide Epidemiological Study. Cyberpsychol Behav Soc Netw 2016;19:557-61.

37. Lee BW, Stapinski LA. Seekingsafety on the internet: relationship between social anxiety and problematic internet use. J Anxiety Disord 2012;26:197-205.

38. Lee YS, Han DH, Kim SM, Renshaw PF. Substance abuse precedes Internet addiction. Addict Behav 2013;38:2022-5.

39. Özcan NK, Buzlu S. Internet use and its relation with the psychosocial situation for a sample of university students. Cyberpsychology Behav 2007;10:767-772.

40. Tao ZL, Liu Y. Is there a relationship between internet dependence and eating disorders? a comparison study of internet dependents and non-internet dependents. Eat Weight Disord 2009;14:e77-e83.

41. Rodgers RF, Melioli T, Laconi S, Bui E, Chabrol H. Internet addiction symptoms, disordered eating, and body image avoidance. Cyberpsychol Behav Soc Netw 2013;16:56-6.
42. Park S, Lee Y. Associations of body weight perception and weight control behaviors with problematic internet use among Korean adolescents. Psychiatry Research 2017;251:275-280.

43. Bener A, Al-Mahdi HS, Ali AI, Al-Nufal M, Vachhani PJ, Tewfik I. Obesity and low vision as a result of excessive Internet use and television viewing. International Journal of Food Sciences \& Nutrition 2011; 62:60-62.

44. Bozkurt H, Özer S, Şahin S, Sönmezgöz E (2017) Internet use patterns and Internet addiction in children and adolescents with obesity. Pediatr Obes 2018;13:301-306.

45. Eliacik K, Bolat N, Koçyiğit C, Kanik A, Selkie E, Yilmaz H, Catli G, Dundar NO, Dundar BN, Internet addiction, sleep and health-related life quality among obese individuals: a comparison study of the growing problems in adolescent health, Eat Weight Disord 2016;21:709-717.

46. Gunuc S, Kayri M. The profile of internet dependency in Turkey and development of internet addiction scale: study of validity and reliability. Hacet Univ J Educ 2010;39:220-232.

47. Bell V. Online information, extreme communities and internet therapy: Is the internet good for our mental health? J. Ment Health 2007;16, 445-457.

48. VanRooij A, Prause N. A critical review of "Internet addiction" criteria with suggestions for the future. J Behav Addict 2014;3:203-213.

49. Musetti A, Cattivelli R, Giacobbi M, Zuglian P, Ceccarini M, Capelli F, Pietrabissa G, Castelnuovo G, Challenges in Internet Addiction Disorder: Is a Diagnosis Feasible or Not? Front Psychol 2016;6;7:842 